Endocrinol. Japon. 1985, 32 (1), 141-152

\title{
Binding of Mibolerone to Androgen Receptor of Benign Hypertrophic Human Prostate. Comparison with R1881
}

\author{
SUSUMU AKIMOTO, HIDEKI FUSE, RYOKO SATO, \\ SHUICHI ZAMA AND JUN SHIMAZAKI
}

Department of Urology, School of Medicine, Chiba University, Chiba 280

\begin{abstract}
The binding nature of mibolerone in cytosols and nuclear extracts from hypertrophic human prostate was examined in comparison with that of $\mathbf{R} 1881$. The binding of mibolerone in the cytosol and nuclear extract was single and of high affinity when evaluated by the method of Scatchard (1949). Binding of mibolerone with testosterone-binding globulin was not detected. The sedimentation coefficients of the binder for mibolerone in the cytosol and nuclear extract were $10.6 \mathrm{~S}$ and $3.6 \mathrm{~S}$, respectively.

When triamcinolone acetonide was induced in the binding medium, inhibition of mibolerone binding in the cytosol by testosterone and dihydrotestosterone was potentiated and this may imply that the binding observed in the presence of triamcinolone acetonide was responsible for the binding of the androgen roceptor. In the nuclear extract, the binding was attributable mainly to the androgen receptor irrespective of the presence or absence of triamcinolone acetonide. These properties of the binding observed in the hypertrophic human prostate were almost same as those of the binding with $\mathrm{R} 1881$.

Although maximum binding sites measured using mibolerone were correlated with those using R 1881 in the cytosols as well as in the nuclear extracts, the values obtained with mibolerone were slightly greater than those with $\mathrm{R} 1881$. Thus, mibolerone seems to be a suitable ligand for measuring the androgen receptor, but when compared with $\mathrm{R} 1881$ no special merits in using mibolerone were detected.
\end{abstract}

It has been accepted that normal and pathological human prostates contain the androgen receptor which may mediate the androgen action in these tissues (Menon et al., 1977 ; Shain and Boese1, 1978). Measurement of the androgen receptor in the human prostate seems to be valuable in basic and clinical studies, since the presence of estrogen receptor in mammary tumors is an apparent

Received November 7, 1984 indicator of the response of the tumors to endocrine therapies (Nomura et al., 1977), and an analogous effect may be expected in the case of prostatic cancer. However, there exist many proteins which interfere with the measurement of androgen receptor in the human prostate. For this reason, several improvements in the estimation of androgen receptor to avoid any binding caused by interfering proteins have appeared (Ghanadian and Auf, 1982). At present, 
the most reliable assay is performed using R 1881 (methyltrienolone, 17 $\beta$-hydroxy-17 $\alpha$ methyl-estra-4, 9, 11-trien-3-one) as ligand in the presence of triamcinolone acetonide $(9 \alpha-$ fluoro-11 $\beta, 16 \alpha, 17,21$-tetra-ol-pregna-1, 4dien-3, 20-dione cyclic 16, 17 acetal with acetone), molybdate and some protease inhibitors such as PMSF (phenyl methyl sulfonyl fluoride) and leupeptin (Zava et al., 1979; Noma et al., 1980; Gaubert et al., 1980 ; Prins and Lee, 1982; Hechter et al., 1983).

Recently, mibolerone ( $7 \alpha, 17 \alpha$-dimethyl19-nortestosterone) was introduced as a new ligand for androgen receptor determination. The present study was undertaken to evaluate the usefulness of this ligand for quantitative determination of androgen receptors and the results obtained were compared with those obtained using R 1881 as the ligand.

\section{Materials and Methods}

\section{Steroids}

Labeled and unlabeled mibolerone $(7 \alpha, 17 \alpha$ dimethyl [17 $\alpha$-methyl- $\left.{ }^{3} \mathbf{H}\right]$ 19-nortestosterone, specific activity $72 \mathrm{Ci} / \mathrm{mmol}$ ) were purchased from Amersham International Plc., Buckinghamshire, England. Labeled and unlabeled R 1881 ( $[17 \alpha-$ methyl- $\left.{ }^{3} \mathrm{H}\right] 17 \beta$-hydroxy- $17 \alpha$-methyl-estra-4, 9, 11trien-3-one, specific activity $87 \mathrm{Ci} / \mathrm{mmol}$ ), labeled dihydrotestosterone $\left(\left[1,2,4,5,6,7-{ }^{3} \mathrm{H}\right] 5 \alpha\right.$-androstan-17 $\beta$-ol-3-one, specific activity $143 \mathrm{Ci} / \mathrm{mmol}$ ) and radioinert $\mathrm{R} 5020$ (promegeston, 17, 21-dimethyl-19-nor-pregna-4, 9-dien-3, 20-dione) were obtained from New England Nuclear, Boston, USA:O OTriamcinolone acetonide was the product of Sigma Chemical Co., St. Louis, USA. Other steroids , used ${ }_{i}$ were donated from Teikoku Hormone.Co., Kawasaki, Japan.

\section{Materials}

Tissues wére óbtained by surgical procedure from patients with benign prostatic hypertrophy admitted to the Chiba. University Hospital. The pathological state of each tissue was confirmed histologically..

Immediately after removal, tissues were cut into small pieces, placed on ice and carried to the laboratory. Some tissues were quickly frozen and kept at $-80^{\circ} \mathrm{C}$ until processing.

When testosterone-binding globulin of the human plasma was used, fraction IV-4 was obtained from the Green Cross Co., Osaka, Japan (Cohn et al., 1946). This fraction was dialyzed, lyophilized and stored at $-80^{\circ} \mathrm{C}$ until use.

\section{Preparation of cytosol}

Tissues were homogenized in 4 volumes of $0.01 \mathrm{M}$ Tris- $\mathrm{HCl}$ buffer ( $\mathrm{pH}$ 7.4) containing $1 \mathrm{mM}$ EDTA, $1 \mathrm{mM} \beta$-mercaptoethanol, $10 \mathrm{mM}$ $\mathrm{Na}_{2} \mathrm{MoO}_{4}$ and $10 \%(\mathrm{w} / \mathrm{v})$ glycerol (TEMMG buffer) using a glass homogenizer and filtered through nylon cloth. After homogenization, PMSF was added to make a final concentration to $0.1 \mathrm{mM}$. Cytosols were obtained as supernatant after centrifuging the homogenates at $105,000 \times \mathrm{g}$ for $60 \mathrm{~min}$.

\section{Preparation of nuclear extract}

Tissues were homogenized in 10 volumes of $0.05 \mathrm{M}$ Tris- $\mathrm{HCl}$ buffer ( $\mathrm{pH}$ 7.4) containing 0.25 $\mathrm{M}$ sucrose, $3 \mathrm{mM} \mathrm{MgCl}$ and $25 \mathrm{mM} \mathrm{KCl}$ (TSMK buffer) supplemented with $0.1 \mathrm{mM}$ PMSF using a glass homogenizer and filtered through nylon cloth. After centrifuging the homogenate at $700 \times \mathrm{g}$ for $10 \mathrm{~min}$, the resultant precipitate was washed with the TSMK buffer containing 0.1 mM PMSF 3 times. The crude nuclear precipitate thus obtained was suspended in the TEMG buffer (omitted molybdate from TEMMG buffer) containing $0.4 \mathrm{M} \mathrm{KCl}$ and stirred at $4^{\circ} \mathrm{C}$ for $30 \mathrm{~min}$. After centrifuging at $8,000 \times \mathrm{g}$ for $20 \mathrm{~min}$, the precipitate was reextracted in the same manner. The combined supernatant was referred to as the nuclear extracts.

\section{Sucrose density gradient centrifugation}

Cytosols prepared in the TEMMG buffer containing $0.1 \mathrm{mM}$ PMSF were incubated with $5 \mathrm{nM}{ }^{3} \mathrm{H}$-mibolerone and $1 \mathrm{mM}$ leupeptin at $4^{\circ} \mathrm{C}$ for $18 \mathrm{~h}$ in the presence of $5 \mu \mathrm{M}$ triamcinolone acetonide. The dextran-coated charcoal $(0.05 \%$ dextran, $0.5 \%$ charcoal) was added, the mixture was centrifuged at $1,000 \times \mathrm{g}$ for $10 \mathrm{~min}$, and an aliquot of the resultant supernatant was fractionated by sucrose density gradient centifugation using a RPS 50-2 rotor in a Hitachi Ultracentrifuge (55P-72, Hitachi Co., Tokyo, Japan) as described previously (Kodama et al., 1984). Nuclear extracts prepared in TEMG buffer containing $0.4 \mathrm{M} \mathrm{KCl}$ and prelabeled with ${ }^{3} \mathrm{H}-$ mibolerone were also fractionated in the similar 
way.

\section{Saturation analysis of the binding}

To calculate binding parameters ( $\mathrm{Kd}$ [dissociation constant] and the number of maximum binding sites [Bmax]) by the method of Scatchard (1949), saturation analysis was performed as described previously (Shimazaki et al., 1981). Briefly, cytosols were incubated in $0.5 \mathrm{ml}$ of the TEMMG buffer with $0.1 \mathrm{mM}$ PMSF containing various concentrations $(0.25-5 \mathrm{nM})$ of ${ }^{3} \mathrm{H}-$ mibolerone or ${ }^{3} \mathrm{H}-\mathrm{R} 1881$ supplemented with a 1000-fold molar excess of triamcinolone acetonide and $1 \mathrm{mM}$ leupeptin at $4^{\circ} \mathrm{C}$ for $18 \mathrm{~h}$. After incubation, dextran-coated charcoal was added, the mixture was centrifuged, and radioactivity in an aliquot of the resultant supernatant was counted in toluene containing $0.4 \%$ PPO and $0.01 \%$ POPOP using a liquid scintillation counter (LKB 1215, Rackbeta, Wallac OY, Finland). In a parallel incubation, a 1000 -fold molar excess of unlabeled ligand was added to the incubation tube and nonspecific binding which was not displaced under these conditions was subtracted in all instances from the total binding to calculate specific binding.

To examine the binding in nuclear extracts, extracts were incubated in TEMG buffer containing various concentrations of labeled ligand, $0.4 \mathrm{M} \mathrm{KCl}$ and $1 \mathrm{mM}$ leupeptin at $4^{\circ} \mathrm{C}$ for 18 h. After incubation, a suspension of hydroxylapatite (Bio-Gel HT, Bio-Rad Laboratories, Richmond, Calif., U.S.A.) in $10 \mathrm{mM}$ Tris-HCl$1 \mathrm{mM} \mathrm{KH_{2 }} \mathrm{PO}_{4}$ buffer ( $\mathrm{pH} \mathrm{7.2,} \mathrm{TK} \mathrm{buffer)} \mathrm{was}$ added, left for $15 \mathrm{~min}$, centrifuged at $1,000 \times \mathrm{g}$ for $5 \mathrm{~min}$, and the supernatant was discarded. The precipitate was washed with TK buffer three times, $2 \mathrm{ml}$ of ethanol was added and left overnight. The mixture was poured into $10 \mathrm{ml}$ of toluene-containing scintillator, the tube was washed with another $1 \mathrm{ml}$ of ethanol and the ethanol was combined with a scintillator, then the radioactivity was counted (Traish et al., 1981).

\section{Analytical methods}

Protein was measured by the biuret method (Gornal et al., 1949) with bovine serum albumin as the calibration standard. DNA was extracted by the method of Hutchison et al. (1962) and measured colorimetrically according to the method of Schneider (1960).

\section{Results}

Binding of ${ }^{3} \mathrm{H}$-mibolerone and ${ }^{3} \mathrm{H}-\mathrm{R} 1881$ to cytosols from hypertrophic human prostate

To examine the effect of incubation time on the binding of $3 \mathrm{H}$-mibolerone, the cytosol was incubated for various time periods in the presence or absence of triamcinolone acetonide (Fig. 1). The binding reached a near plateau by $18 \mathrm{~h}$ after the start of the incubation. The presence of triamcinolone acetonide did not modify the time course of the binding. Therefore, subsequent incubations with ${ }^{3} \mathrm{H}$-mibolerone were performed for 18 h.

The binding of ${ }^{3} \mathrm{H}-\mathrm{mibolerone}$ to the cytosol showed a single high affinity pattern (Fig. 2). The addition of triamcinolone acetonide reduced $B \max$ by approximately $50 \%$ and $\mathrm{Kd}$ was diminished to some extent. Binding sites for ${ }^{3} \mathrm{H}-\mathrm{R} 1881$ in the same cytosol were smaller than those for $3 \mathrm{H}$ mibolerone (Fig. 2). The effect of triamcinolone acetonide on the binding of ${ }^{3} \mathrm{H}-\mathrm{R} 1881$ was also noticed.

Although ${ }^{3} \mathrm{H}$-dihydrotestosterone showed

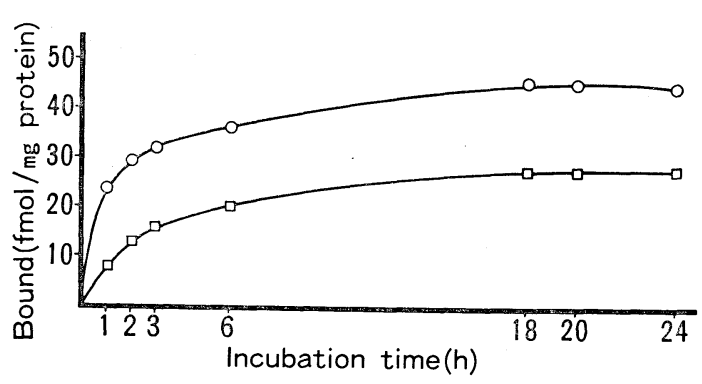

Fig. 1. Time course of the binding of ${ }^{3} \mathrm{H}$ mibolerone to the cytosol from hypertrophic human prostate. Cytosols $(2.0 \mathrm{mg}$ as protein/ tube) were incubated with $1 \mathrm{nM}{ }^{3} \mathrm{H}$-mibolerone, $10 \mathrm{mM}$ molybdate, $0.1 \mathrm{mM}$ phenyl methyl sulfonyl fluoride and $1 \mathrm{mM}$ leupeptin in the presence (open square) or absence (open circle) of $1 \mu \mathrm{M}$ triamcinolone acetonide for the time intervals indicated. The specific binding is depicted. 
a high affinity binding with testosteronebinding globulin in blood plasma, there was no measurable binding to this protein of ${ }^{3} \mathrm{H}$-mibolerone or of $3 \mathrm{H}-\mathrm{R} 1881$ (Fig. 3).

The cytosol prelabeled with $5 \mathrm{nM}{ }^{3} \mathrm{H}$ mibolerone in the presence of $5 \mu \mathrm{M}$ triamcinolone acetonide was fractionated in a sucrose density gradient centrifugation (Fig. 4). A radioactive peak of ${ }^{3} \mathrm{H}$-mibolerone

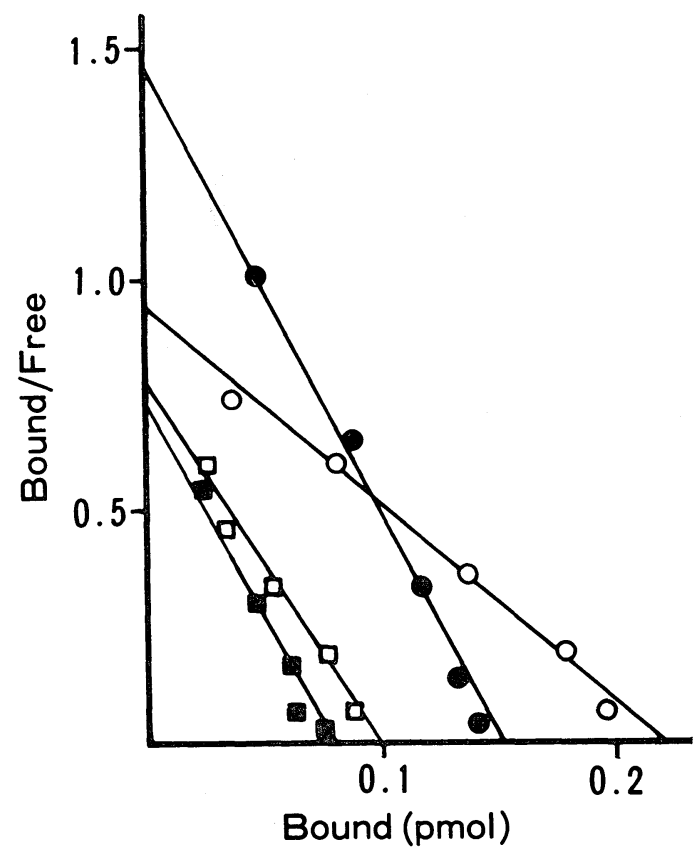

Fig. 2. Binding of ${ }^{3} \mathrm{H}$-mibolerone and ${ }^{3} \mathrm{H}-\mathrm{R}$ 1881 to the cytosol from hypertrophic human prostate. Cytosols $(3.0 \mathrm{mg}$ as protein/tube) were incubated with various concentrations (0.25-5 nM) of ${ }^{3} \mathrm{H}$-mibolerone or ${ }^{3} \mathrm{H}-\mathrm{R} 1881$ in the presence or absence of 1000 -fold molar excess of triamcinolone acetonide at $4^{\circ} \mathrm{C}$ for $18 \mathrm{~h}$. Dissociation constant $(\mathrm{Kd})$ and number of maximum binding sites (Bmax) calculated from the Fig. are : $0.5 \times 10^{-9} \mathrm{M}$ and $76 \mathrm{fmol} /$ mg protein $\left({ }^{3} \mathrm{H}\right.$-mibolerone, open circle) and $0.2 \times 10^{-9} \mathrm{M}$ and $52 \mathrm{fmol} / \mathrm{mg}$ protein $\left({ }^{3} \mathrm{H}-\mathrm{R}\right.$ 1881 , closed circle) in the absence of triamcinolone acetonide, $0.3 \times 10^{-9} \mathrm{M}$ and 34 $\mathrm{fmol} / \mathrm{mg}$ protein $\left({ }^{3} \mathrm{H}\right.$-mibolerone, open square) and $0.2 \times 10^{-9} \mathrm{M}$ and $27 \mathrm{fmol} / \mathrm{mg}$ protein $\left({ }^{3} \mathrm{H}-\right.$ $R 1881$, closed square) in the presence of triamcinolone acetonide, respectively. was observed at the site of $10.6 \mathrm{~S}$, and this site was identical to that prelabeled with 3H-R 1881 (data not shown).

To examine the effect of various steroids on the binding of ${ }^{3} \mathrm{H}$-mibolerone, the cytosol was incubated with $1 \mathrm{nM}{ }^{3} \mathrm{H}$-mibolerone supplemented various concentrations (101,000 nM) of additives (Fig. 5). R 1881 was a potent inhibitor of the binding and the rate of inhibition by $R 1881$ was the same

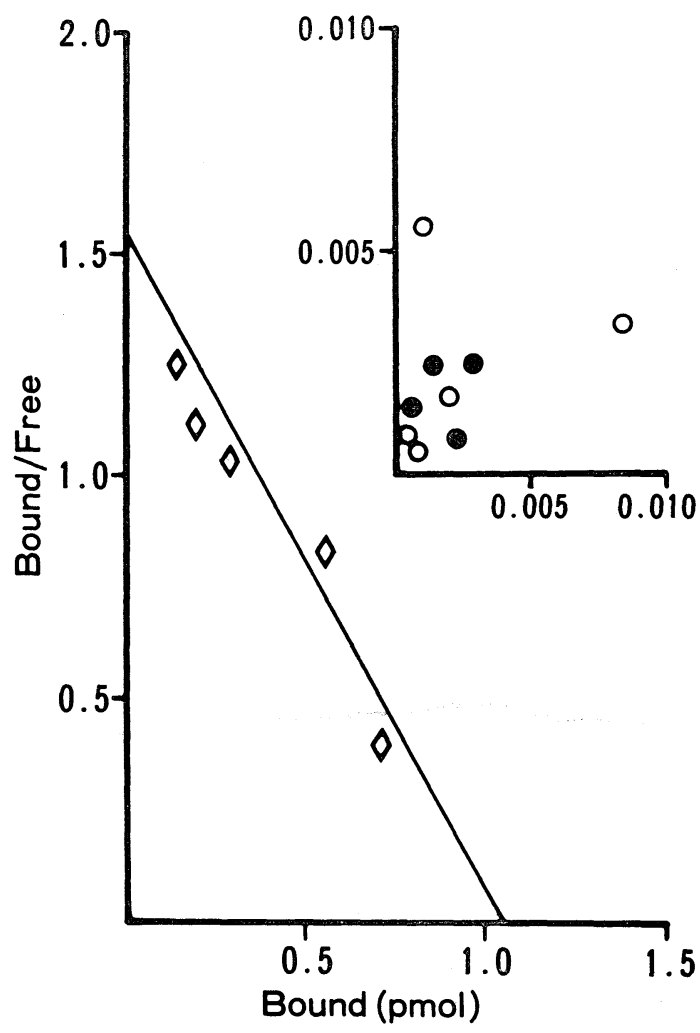

Fig. 3. Binding of ${ }^{3} \mathrm{H}$-mibolerone, ${ }^{3} \mathrm{H}-\mathrm{R} 1881$ and ${ }^{3} \mathrm{H}$-dihydrotestosterone to the testosteronebinding globulin. Testosterone-binding globulin $\left(3.5 \mathrm{mg}\right.$ for ${ }^{3} \mathrm{H}$-mibolerone [open circle] and ${ }^{3} \mathrm{H}-\mathrm{R} 1881$ [closed circle], or $0.5 \mathrm{mg}$ for ${ }^{3} \mathrm{H}$ dihydrotestosterone [open diamond] as protein of fraction IV-4/tube) was incubated with various concentrations of respective ligands at $4^{\circ} \mathrm{C}$ for $2 \mathrm{~h}$. $\mathrm{Kd}$ and Bmax calculated from the Fig. for dihydrotestosterone are $1.4 \times 10^{-9} \mathrm{M}$ and $2,100 \mathrm{fmol} / \mathrm{mg}$ protein. 
as that by mibolerone. The inhibition by dihydrotestosterone and cyproterone acetate was rather weak, and the rate of inhibition induced by the addition of testosterone, progesterone and R 5020 was quite similar. Diethylstilbestrol did not exhibit any inhibitions. When triamcinolone acetonide was added to the incubation experiments,

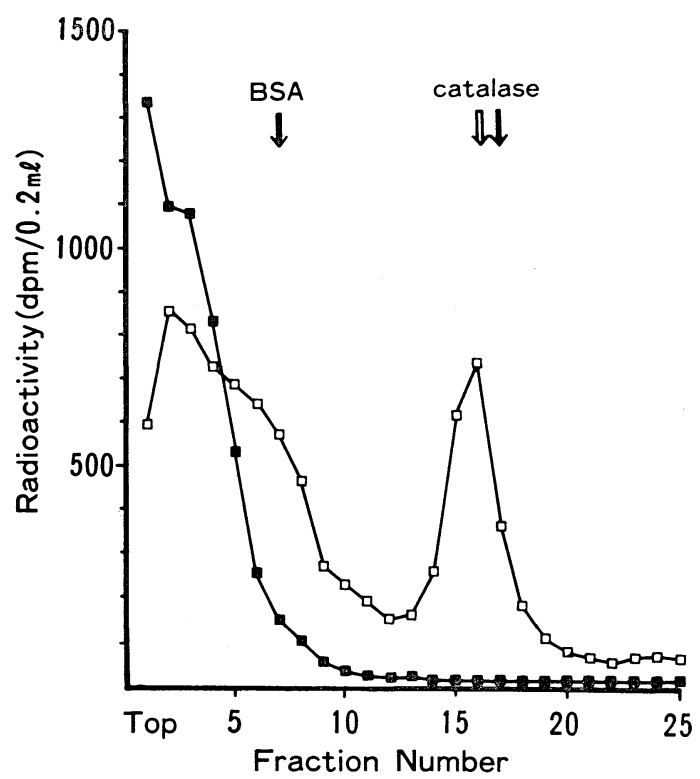

Fig. 4. Sucrose density gradient centrifugation of the cytosol from hypertrophie human prostate prelabeled with ${ }^{3} \mathrm{H}$-mibolerone.

Cytosols were incubated with $5 \mathrm{nM}{ }^{3} \mathrm{H}$ mibolerone in the presence of $5 \mu \mathrm{M}$ triamcinolone acetonide at $4^{\circ} \mathrm{C}$ for $18 \mathrm{~h}$. After separating unbound steroid with dextrancoated charcoal, an aliquot $(0.3 \mathrm{ml}, 1.5 \mathrm{mg}$ as protein) was applied on the top of a 5$20 \%$ sucrose gradient $(5 \mathrm{ml})$ in the TEMMG buffer containing $1 \mathrm{mM}$ leupeptin, and centrifuged at $165,500 \times \mathrm{g}$ for $16 \mathrm{~h}$. Each fraction of $0.2 \mathrm{ml}$ was collected and radioactivity was counted (open square). In a parallel experiment, cytosol prelabeled in the presence of 5 $\mu \mathrm{M}$ radioinert mibolerone was used to observe nonspecific binding (closed square). The site of the binding component is indicated by an empty arrow. Black arrows indicate the location of markers (BSA: bovine serum albumin ; $4.6 \mathrm{~S}$, catalase ; $11.3 \mathrm{~S}$ ).
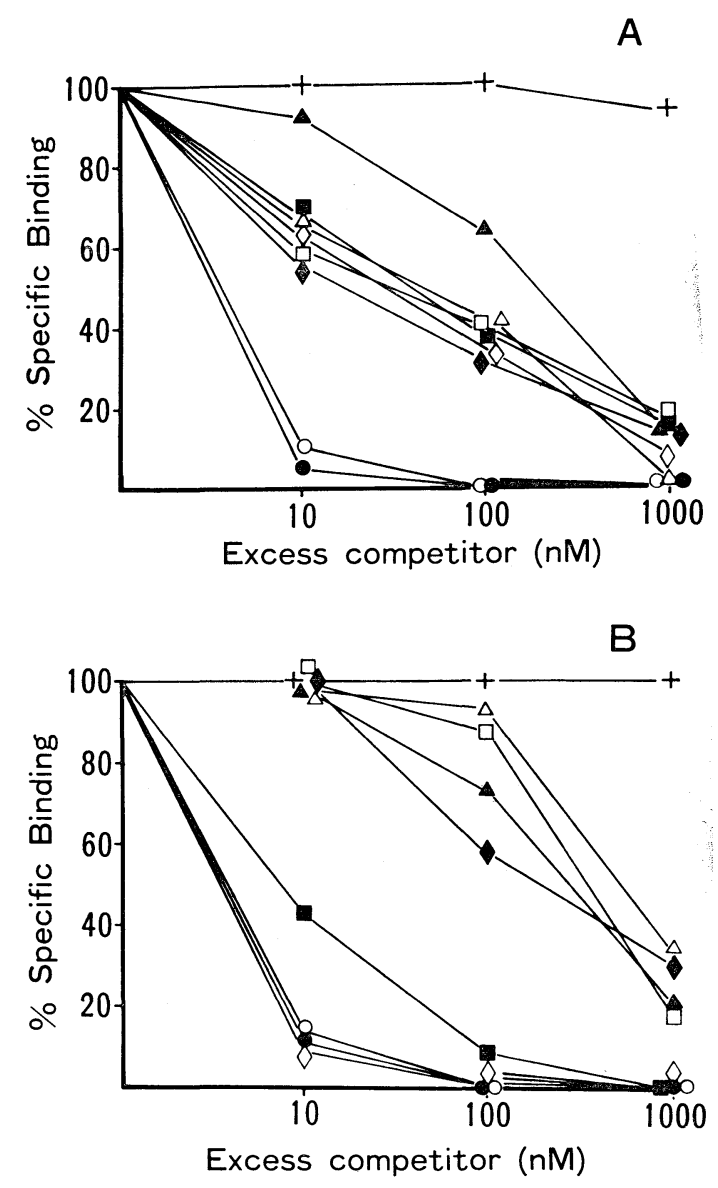

Fig. 5. Inhibition of binding of ${ }^{3} \mathrm{H}$-mibolerone to the cytosol from hypertrophic human prostate by various steroids.

Cytosols $(2.7 \mathrm{mg}$ as protein/tube) were incubated with $1 \mathrm{nM}{ }^{3} \mathrm{H}$-mibolerone in the presence of various steroids (A). In the experiment depicted in (B), $1 \mu \mathrm{M}$ of triamcinolone acetonide was included. Results are expressed as percent binding of the binding obtained without inhibitors (A: $37 \mathrm{fmol} / \mathrm{mg}$ protein, $\mathrm{B}: 18 \mathrm{fmol} / \mathrm{mg}$ protein). Inhibiting steroids used are as follows: mibolerone (open circle), R 1881 (closed circle), dihydrotestosterone (open diamond), cyproterone acetate (closed diamond), R 5020 (open square), testosterone (closed square), progesterone (open triangle), estradiol-17 $\beta$ (closed triangle), diethylstilbestrol (cross). 
dihydrotestosterone and testosterone provoked a potent inhibition, but inhibition by cyproterone acetate, estradiol-17 $\beta$, and progestational steroids was still weak. From these inhibition experiments, ${ }^{3} \mathrm{H}$-mibolerone seems to bind with some binding proteins in the cytosol, but binding of this ligand in the presence of triamcinolone acetonide seems to be specific for the androgen receptor. The pattern of inhibition of the binding of $3 \mathrm{H}$-mibolerone by various steroids was almost identical to that of ${ }^{3} \mathrm{H}-\mathrm{R} 1881$, which has already been reported (Shimazaki et al., 1981).

Binding of ${ }^{3} \mathrm{H}$-mibolerone and ${ }^{3} \mathrm{H}-\mathrm{R} 1881$ to nuclear extracts from hypertrophic human

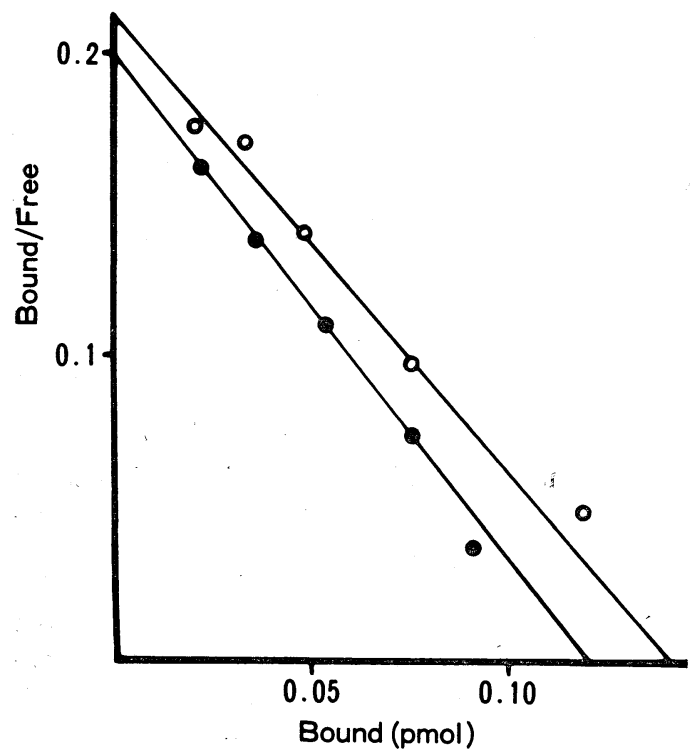

Fig. 6. Binding of ${ }^{3} \mathrm{H}-$ mibolerone and ${ }^{3} \mathrm{H}-\mathrm{R}$ 1881 to the nuclear extract from hypertrophic human prostate. Nuclear extracts prepared with $0.4 \mathrm{M} \mathrm{KCl}(1.5 \mathrm{mg}$ as protein/tube) were incubated with various concentrations of ${ }^{3} \mathrm{H}$-mibolerone (open circle) or ${ }^{3} \mathrm{H}-\mathrm{R} 1881$ (closed circle) at $4^{\circ} \mathrm{C}$ for $18 \mathrm{~h} . \mathrm{Kd}$ and Bmax calculated from the Fig. are : $1.3 \times 10^{-9}$ M, $93 \mathrm{fmol} / \mathrm{mg}$ protein or $587 \mathrm{fmol} / \mathrm{mg}$ DNA ( ${ }^{3} \mathrm{H}$-mibolerone), and $1.2 \times 10^{-9} \mathrm{M}, 79 \mathrm{fmol} /$ $\mathrm{mg}$ protein or $496 \mathrm{fmol} / \mathrm{mg}$ DNA ( $\left.{ }^{3} \mathrm{H}-\mathrm{R} 1881\right)$, respectively. prostate

The binding of ${ }^{3} \mathrm{H}$-mibolerone and $3 \mathrm{H}-\mathrm{R}$ 1881 to the nuclear extract prepared with $0.4 \mathrm{M} \mathrm{KCl-containing} \mathrm{TEMG} \mathrm{buffer} \mathrm{was}$ examined (Fig. 6). A single high affinity binding was shown in the binding of these

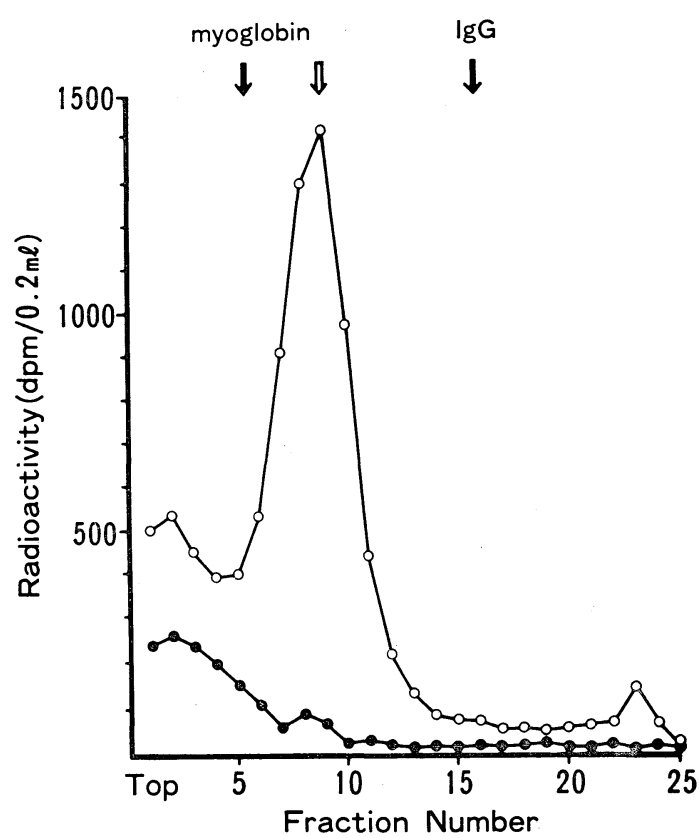

Fig. 7. Sucrose density gradient centrifugation of the nuclear extract from hypertrophic human prostate prelabeled with ${ }^{3} \mathrm{H}$-mibolerone.

Nuclear extracts were incubated with 5 $\mathrm{nM}$ of ${ }^{3} \mathrm{H}$-mibolerone, $04 \mathrm{M} \mathrm{KCl}$ and $1 \mathrm{mM}$ leupeptin at $4^{\circ} \mathrm{C}$ for $18 \mathrm{~h}$. After separating unbound steroid with dextran-coated charcoal, an aliquot $(0.3 \mathrm{ml}, 0.5 \mathrm{mg}$ as protein) was applied on the top of a 5-20\% sucrose gradient $(5 \mathrm{ml})$ in TEMG buffer containing $0.4 \mathrm{M} \mathrm{KCl}$ and $1 \mathrm{mM}$ leupeptin, and centrifuged at $215,000 \times \mathrm{g}$ for $25 \mathrm{~h}$. $0.2 \mathrm{ml}$ fractions were collected and the radioactivity of each was counted (open circle). In a parallel incubation, nuclear extract prelabeled in the presence of $5 \mu \mathrm{M}$ radioinert mibolerone was used to observe nonspecific binding (closed circle). The site of the binding component is indicated by an empty arrow. Black arrows indicate the location of markers (myoglobin: $2.1 \mathrm{~S}, \mathrm{IgG}$; human immunoglobulin $\mathrm{G}: 7.0 \mathrm{~S})$. 
two ligands. The addition of triamcinolone acetonide did not modify the binding of these two ligands to the nuclear extract (data not shown).

The nuclear extract prelabeled with $5 \mathrm{nM}$ ${ }^{3} \mathrm{H}$-mibolerone was fractionated in a sucrose density gradient centrifugation (Fig. 7). A radioactive peak of $3 \mathrm{H}$-mibolerone was detected at the site corresponding to $3.6 \mathrm{~S}$,

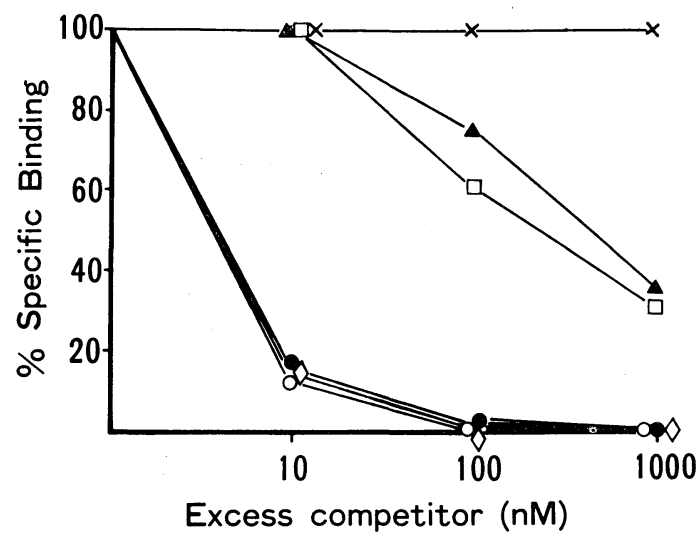

Fig. 8. Inhibition of binding of ${ }^{3} \mathrm{H}$-mibolerone to the nuclear extract from hypertrophic human prostate by various steroids.

Nuclear extracts $(2.1 \mathrm{mg}$ as protein/tube) were incubated with $1 \mathrm{nM}{ }^{3} \mathrm{H}$-mibolerone in the presence or absence of various steroids. Results are expressed as percent binding of the binding obtained without inhibitors (56 fmol/mg protin, $460 \mathrm{fmol} / \mathrm{mg}$ DNA). Inhibiting steroids used are as follows: mibolerone (open circle), R 1881 (closed circle), dihydrotestosterone (open diamond), R 5020 (open square), estradiol-17 $\beta$ (closed triangle), triamcinolone acetonide (cross). and this site was also observed in the binding of ${ }^{3} \mathrm{H}-\mathrm{R} 1881$ to the nuclear extract (data not shown).

The effect of the addition of various steroids on the binding of ${ }^{3} \mathrm{H}$-mibolerone to the nuclear extract was examined (Fig. 8). Potent inhibition of an almost identical degree to the binding was noticed following the addition of $\mathrm{R} 1881$, mibolerone or dihydrotestosterone, but a supplement of triamcinolone acetonide to the incubation mixture did not show any effect on the binding. Therefore, the binding of ${ }^{3} \mathrm{H}$ mibolerone to the nuclear extract may be mainly attributable to the androgen receptor, and this was quite analogous to the binding of $3 \mathrm{H}-\mathrm{R} 1881$ to the nuclear extract (Kodama et al., 1980).

Comparison of the binding of ${ }^{3} \mathrm{H}$-mibolerone with that of ${ }^{3} \mathrm{H}-\mathrm{R} 1881$ to androgen receptor

The binding of ${ }^{3} \mathrm{H}$-mibolerone and $3 \mathrm{H}$ R 1881 to the cytosol and the nuclear extract from the hypertrophic human prostates was examined simultaneously by saturation analysis, and the binding parameters were compared (Table 1). The Kd's of these two ligands were almost identical. The Bmax for these ligands correlated well in both cytosols and nuclear extracts (Fig. 9), but the values obtained with $3 \mathrm{H}$-mibolerone were somewhat higher than those with ${ }^{3} \mathrm{H}-\mathrm{R} 1881$ in both cytosols and nuclear extracts.

Table 1. Comparison of androgen receptors in cytosols and nuclear extracts of hypertrophic human prostates estimated with ${ }^{3} \mathrm{H}$-mibolerone and ${ }^{3} \mathrm{H}-\mathrm{R} 1881$.

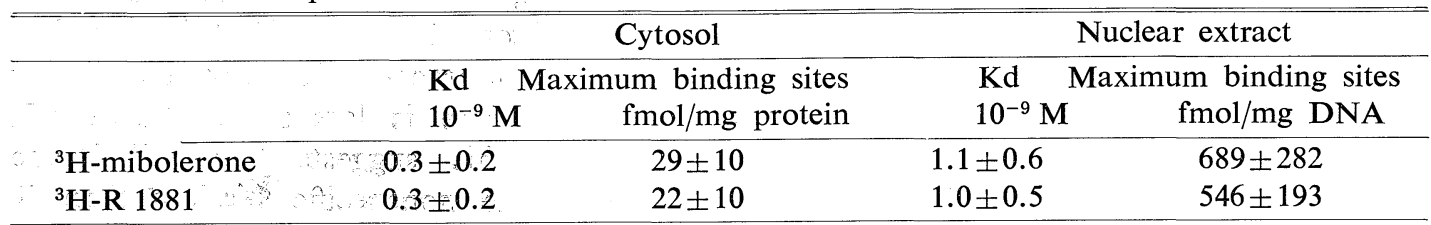

Data are shown as $\mathbf{M} \pm \mathbf{S} . \mathrm{D}$. Cytosols were incubated in the presence of 1000 -fold molar excess of triamcinolone acetonide. Numbers of cytosol and nuclear extract assayed were 10 and 8 , respectively? 


\section{Cytosol}

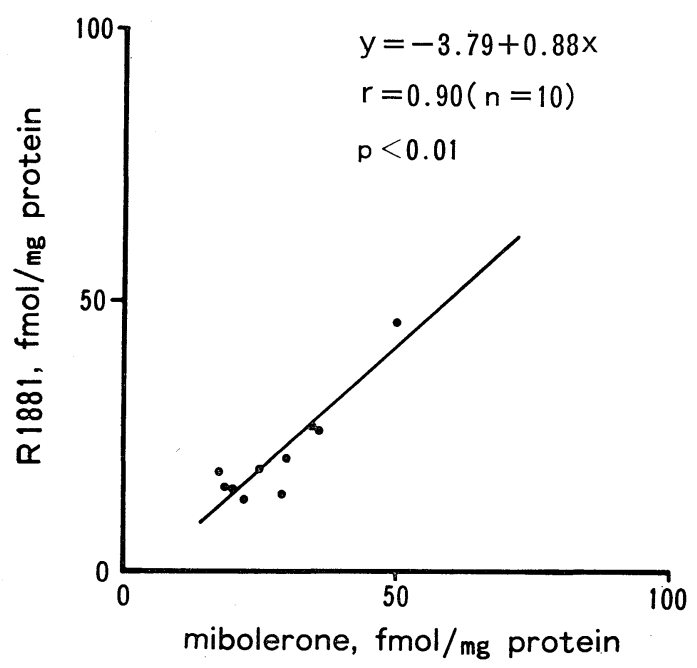

Nuclear extract

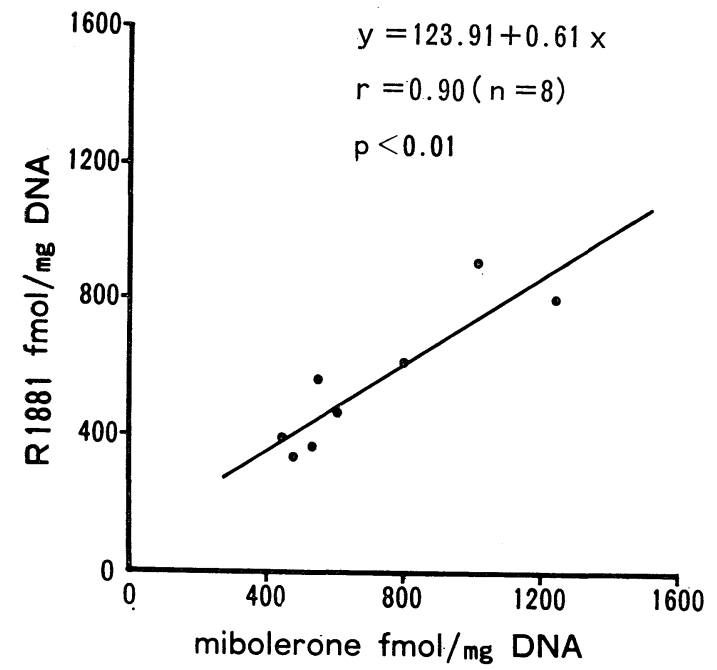

Fig. 9. Comparison of the binding with ${ }^{3} \mathrm{H}^{-}$ mibolerone to that with ${ }^{3} \mathrm{H}-\mathrm{R} 1881$ in cytosols and nuclear extracts from hypertrophic human prostates.

Bmax of the androgen receptor was measured simultaneously in the same preparations using ${ }^{3} \mathrm{H}$-mibolerone (abscissa) and ${ }^{3} \mathrm{H}-\mathrm{R} 1881$ (ordinate) supplemented 1000 -fold molar excess of triamcinolone acetonide.

\section{Discussion}

Although the human prostate contains testosterone-binding protein which may be derived from the blood plasma (Cowan et al., 1976; Dennis et al., 1977; Mobbs et al., 1977), $\mathrm{R} 1881$ does not bind with this protein (Bonne and Raynaud, 1976; Ghanadian et al., 1978). This is one of the advantages in using R 1881 to examine the androgen receptor in human samples, and the use of this ligand for quantitative determination of the androgen receptor has been stressed. In the present study, no significant binding of mibolerone to the testosterone-binding globulin was observed as is noticed with $\mathrm{R} 1881$. On the other hand, the disadvantage of applying $\mathrm{R} 1881$ to measure the androgen receptor is due to the fact that this ligand binds to progestinbinding component(s) in addition to the androgen receptor in the human prostate (Menon et al., 1978). It was reported by Zava et al. (1979) and Asselin et al. (1978) that the addition of triamcinolone acetonide inhibited the binding of R 1881 with progestin-binding component(s), thereafter measurement of the androgen receptor in the human prostate has been performed with this ligand in the presence of triamcinolone acetonide (Hicks and Walsh, 1979; Trachtenberg et al., 1981, 1982; Shain et al., 1980; Ekman et al., 1982; Wilbert et al., 1983). In the present study, it is revealed in the inhibition experiments that mibolerone also binds not only to the androgen receptor but also to other binding components, being almost identical to the binding observed in R 1881 (Shimazaki et al., 1981). Moreover, $\mathrm{Kd}$ for the binding with mibolerone is larger than that for $\mathbf{R}$ 1881 , and this suggests that mibolerone binds to more nonspecific binders than $R$ 1881 (Fig. 2, absence of triamcinolone acetonide). The addition of triamcinolone acetonide when incubating the cytosol with 
mibolerone reveals a single binding which seems to be due to the androgen receptor. Therefore, the binding specificity of mibolerone is considered to be almost identical to that of R 1881 .

The maximum binding sites of the androgen receptor obtained from the incubation with mibolerone are slightly larger than those of $\mathrm{R} 1881$. The reason for this differe nces in the maximum binding sites of these two ligands has not been fully elucidated. However, one possible explanation is that the rate of exchange of preoccupied androgen receptors by ${ }^{3} \mathrm{H}-$ mibolerone is higher than that by ${ }^{3} \mathrm{H}-\mathrm{R} 1881$, since the binding affinity of mibolerone is higher than that of other androgens including R 1881 (Liao et al., 1973). Although the present experiments show almost identical $\mathrm{Kd}$ for mibolerone and $\mathrm{R} 1881$ in the binding with androgen receptor, preliminary experiments on the rate of exchange of the preoccupied cytosolic androgen receptor showed more than $80 \%$ by mibolerone, and this seems to be slightly more effective than by R 1881 (Nozumi et al., 1981). Alternatively, the higher stability of mibolerone may explain the higher maximum binding sites, since R 1881 is relatively unstable due to photolability(Randall and Mainwaring, 1984). From these results, it may be concluded that mibolerone is a suitable ligand for determination of androgen receptors, but the binding properties of this ligand are almost the same as those of $\mathrm{R} 1881$ and the distinct superiority of this ligand over R 1881 is not proved. The binding parameters with mibolerone in the hypertrophic human prostates obtained in this study are in the same range to those examined as androgen receptor by others (Ekman et al., 1979; Ghanadian and Auf, 1982; Sirett and Grant, 1982 ; Barrack et al., 1983; Hernandez et al., 1983).

When R 5020, a specific ligand for the progestin receptor, and cytosol of the human prostate are incubated, a considerable amount of high affinity binding has been observed
(Gustafsson et al., 1978). From the similarity in steroid specificity, binding parameters and sedimentation coefficient between the progestin receptor in the uterus and the binder for R 5020 in the human prostate, it has been suggested that the binder of the human prostate is the progestin receptor per se (Bashirelahi et al., 1983ab; Schneider et al., 1984). However, we previously claimed that the progestin-binding component(s) in the human prostate is not the progestin receptor, since the nuclear extract of the human prostate does not bind with R 5020 (Kodama et al., 1981). Although R 1881 binds to the progestin receptor in a high affinity, it was reported by Wilks et al. (1980) that the binding affinity of mibolerone to the uterine progesterone receptor of hamster is relatively low. Together with the results of the present finding that triamcinolone acetonide almost equally inhibits the bindings of mibolerone and $\mathrm{R} 1881$, it seems to be quite unlikely that the progestin-binding component(s) in the hypertrophic human prostate is the progestin receptor. However, at variance with the observation of Wilks et al. (1980), Delettre et al. (1980) reported that the binding of the progestin receptor in uterine cytosol of rabbit to mibolerone is of high affinity and is not different from that to R 1881 .

For accurate determination of steroid hormone receptors, it seems to be ideal to use a ligand which is specific to individual receptor. Unfortunately it is revealed that mibolerone is not specific to the androgen receptor of the human prostate. Further studies to explore more suitable ligands for the androgen receptor will be awaited.

\section{Acknowledgements}

This work was supported in part by Grantsin-Aid for Cancer Research from the Ministry of Health and Welfare and from the Ministry of Education, Science and Culture, and for 
Scientific Research from the Ministry of Education, Science and Culture, Japan.

\section{References}

Asselin, J., R. Melancon, Y. Gourdeau, F. Labrie, C. Bonne and J. P. Raynaud (1979). Specific binding of $\left({ }^{3} \mathrm{H}\right)$-methyltrienolone to both progestin and androgen binding components in human benign prostatic hypertrophy (BPH). J. Steroid Biochem. 10, 483-486.

Barrack, E. R., P. Bujnovszky and P. C. Walsh (1983). Subcellular distribution of androgen receptors in human normal, benign hyperplastic, and malignant prostatic tissues : Characterization of nuclear salt-resistant receptors. Cancer Res. 43, 1107-1116.

Bashirelahi, N., T. Beckerman and D. Young, Jr. (1983a). Distribution of specific binding of $\left({ }^{3} \mathrm{H}\right)$-promegestone in benign prostatic hypertrophy in regard to age, race and histological differences. J. Steroid Biochem. 19, 1757-1761.

Bashirelahi, N., C. C. Felder and J. D. Young (1983b). Characterization and stabilization of progesterone receptors in human benign prostatic hypertrophy. J. Steroid Biochem. 18, 801-809.

Bonne, C. and J. P. Raynaud (1976). Assay of androgen binding sites by exchange with methyltrienolone (R 1881). Steroids 27, 497507.

Cohn, E. J., L. E. Strong, W. L. Hughes, Jr., D. J. Mulford, J. N. Ashworth, M. Melin and H. L. Taylor (1946). Preparation and properties of serum and plasma proteins IV. A system for the separation into fractions of the protein and lipoprotein components of biological tissues and fluids. J. Am. Chem. Soc. 68, 459-475.

Cowan, R. A., S. K. Cowan, C. A. Giles and J. K. Grant (1976). Prostatic distribution of sex hormone-binding globulin and cortisolbinding globulin in benign hyperplasia. $J$. Endocrinol. 71, 121-131.

Delettre, J., J. P. Mornon, G. Lepicard, T. Ojasoo and J. P. Raynaud (1980). Steroid flexibility and receptor specificity. J. Steroid Biochem. 13, 45-59.

Dennis, M., H. J. Horst, M. Krieg and K. D. Voigt (1977). Plasma sex hormone-binding globulin binding capacity in benign prostatic hypertrophy and prostatic carcinoma: Comparison with an age dependent rise in normal human males. Acta Endocrinol. 84, 207-214.

Ekman, P., M. Snochowski, E. Dahlberg, D. Bression, B. Högberg and J. A. Gustafsson (1979). Steroid receptor content in cytosol from normal and hyperplastic human prostates. J. Clin. Endocrinol. Metab. 49, 205-215.

Ekman, P., E. R. Barrack and P. C. Walsh (1982). Simultaneous measurement of progesterone and androgen receptors in human prostate: A microassay. J. Clin. Endocrinol. Metab. 55, 1089-1098.

Gaubert, C. M., R. R. Tremblay and J. Y. Dube (1980). Effect of sodium molybdate on cytosolic androgen receptors in rat prostate. $J$. Steroid Biochem. 13, 931-937.

Ghanadian, R. and G. Auf (1982). Analysis of steroid receptors in the prostate. In "The Endocrinology of Prostate Tumours" (R. Ghanadian, ed.) MTP Press Ltd., Lancaster, pp. 171-219.

Ghanadian, R., G. Auf, P. J. Chaloner and G. D. Chisholm (1978). The use of methyltrienolone in the measurement of the free and bound cytoplasmic receptors for dihydrotestosterone in benign hypertrophied human prostate. $J$. Steroid Biochem. 9, 325-330.

Gornall, A. G., C. J. Bardawill and M. M. David (1949). Determination of serum proteins by means of the biuret reaction. J. Biol. Chem. 177, 751-766.

Gustafsson, J. A., P. Ekman, A. Pousette, M. Snochowski and B. Högberg (1978). Demonstration of a progestin receptor in human benign prostatic hyperplasia and prostatic carcinoma. Invest. Urol. 15, 361-366.

Hechter, O., D. Mechaber, A. Zwick, L. A. Campfield, B. Eychenne, E. E. Baulieu and P. Robel (1983). Optimal radioligand exchange conditions for measurement of occupied androgen receptor sites in rat ventral prostate. Arch. Biochem. Biophys. 224, 49-68.

Hernandez, J. J.C., J. M. M. Garcia, P. A. Hoisaeter, T. Martin, L. C. G. Diez and J. M. Gomez (1983). Relations between circulating levels of testosterone, $17 \beta$-estradiol, androstenedione, dehydroepiandrosterone sulfate, and androgenic receptor content of cytosol in benign prostatic hyperplasia. Urol. Internat. $38,109-115$.

Hicks, L. L. and P. C. Walsh (1979). A microassay for the measurement of androgen re- 
ceptors. Steroids 33, 389-406.

Hutchison, W. C., E. D. Downie and H. N. Munro (1962). Factors affecting the Schneider procedure for estimation of nucleic acids. Biochem. Biophys. Acta 55, 561-570.

Kodama, T., H. Fuse and J. Shimazaki (1984). Low molecular weight component of androgen receptor in cytosols from benign hypertrophic human prostate treated with high $\mathrm{KCl}$ solution. Endocrinol. Japon. 29, 325-333.

Kodama, T., C. Hasebe and J. Shimazaki (1980). Binding to R 1881 (methyltrienolone) of proteins from human benign prostatic hypertrophy. Endocrinol. Japon. 27, 229-237.

Kodama, T., M. Ito, R. Sato, H. Ito and J. Shimazaki (1981). Progestin-binding protein in human benign prostatic hypertrophy. Endocrinol. Japon. 28, 175-185.

Liao, S., T. Liang, S. Fang, E. Castaneda and T. C. Shao (1973). Steroid structure and androgenic activity. J. Biol. Chem. 248, 61546162.

Menon, M., C. E. Tananis, L. L. Hicks and E. F. Hawkins (1978). Characterization of the binding of a potent synthetic androgen, methyltrienolone, to human tissues. J. Clin. Invest. 61, 150-162.

Menon, M., C. E. Tananis, M. G. McLoughlin and P. C. Walsh (1977). Androgen receptors in human prostatic tissue: A review. Cancer Treat. Rep. 61, 265-271.

Mobbs, B. G., I. E. Johnson, J. G. Connolly and A. F. Clark (1977). Evaluation of the use of cyproterone acetate competition to distinguish between high-affinity binding of $\left({ }^{3} \mathrm{H}\right)$-dihydrotestosterone to human prostate cytosol receptors and to sex hormone-binding globulin. $J$. Steroid Biochem. 8, 943-949.

Noma, K., K. Nakao, B. Sato, Y. Nishizawa, K. Matsumoto and Y. Yamamura (1980). Effect of molybdate on activation and stabilization of steroid receptors. Endocrinology 107, 1205-1211.

Nomura, Y., S. Kobayashi, O. Takatani, H. Sugano, K. Matsumoto and W. L. McGuire (1977). Estrogen receptor and endocrine responsiveness in Japanese versus American breast cancer patients. Cancer Res. 37, 106110.

Nozumi, K., R. Sato, H. Ito, M. Maruoka and J. Shimazaki (1981). Binding of dihydrotestosterone, R 1881 and R 5020 in cytosols from normal, benign hypertrophic and cancerous human prostates. Urol. Internat. 36, 79-87.

Prins, G. S. and C. Lee (1982). Effect of protease inhibitors on androgen receptor analysis in rat prostate cytosol. Steroids 40, 189-207.

Randall, V. A. and W. I. P. Mainwaring (1984). Preliminary investigations of a new radioligand, $\left({ }^{3} \mathrm{H}\right)$-mibolerone, for use in androgen receptor research. Abstracts of 7 th Internat. Congress of Endocrinology, July, Quebec, Canada, p. 1199.

Scatchard, G. (1949). The attractions of proteins for small molecules and ions. Ann. N. Y. Acad. Sci. 51, 660-672.

Schneider, S. L., J. E. Pontes, J. M. Greco, G. P. Murphy and A. A. Sandberg (1984). Characterization of $7-8 \mathrm{~S}$ progestin binding protein in human prostate using vertical tube rotor. J. Steroid Biochem. 20, 715-723.

Schneider, W.C. (1960). Determination of nucleic acids in tissues by pentose analysis. Methods in Enzymol. 3, 680-684.

Shain, S. A. and R. W. Boesel (1978). Human prostate steroid hormone receptor quantitation. Current methodology and possible utility as a clinical discriminant in carcinoma. Invest. Urol. 16, 169-174.

Shain, S. A., R. W. Boesel, D. L. Lamm and H. M. Radwin (1980). Cytoplasmic and nuclear androgen receptor content of normal and neoplastic human prostates and lymph node metastases of human prostatic adenocarcinoma. J. Clin. Endocrinol. Metab. 50, 704-711.

Shimazaki, J., T. Hikage, R. Sato, T. Kodama and H. Ito (1980). Measurement of androgen receptor in cytosols from normal, benign hypertrophic and cancerous human prostates. Endocrinol. Japon. 28, 725-734.

Sirett, D. A. N. and J. K. Grant (1982). Effect of sodium molybdate on the interaction of androgens and progestins with binding proteins in human hyperplastic prostatic tissue. J. Endocrinol. 92, 95-102.

Trachtenberg, J., P. Bujnovszky and P.C. Walsh (1982). Androgen receptor content of normal and hyperplastic human prostate. J. Clin. Endocrinol. Metab. 54, 17-21.

Trachtenberg, J., L. L. Hicks and P. C. Walsh (1981). Methods for the determination of androgen receptor content in human prostatic tissue. Invest. Urol. 18, 349-354.

Traish, A. M., R. E. Muller and H. H. Wotiz (1981). A new procedure for the quantitation of nuclear and cytoplasmic androgen receptors. 
J. Biol. Chem. 256, 12028-12033.

Wilbert, D. M., J. E. Griffin and J. D. Wilson

(1983). Characterization of the cytosol androgen receptor of the human prostate. $J$. Clin. Endocrinol. Metab. 56, 113-120.

Wilks, J.W., C.H. Spilman and J.A. Campbell (1980). Steroid binding specificity of the hamster uterine progesterone receptor. Steroids 35, 697-706.

Zava, D. T., B. Landrum, K. B. Horwitz and W. L. McGuire (1979). Androgen receptor assay with $\left({ }^{3} \mathrm{H}\right)$ methyltrienolone $(\mathrm{R}, 18.81)$ in the presence of progesterone receptors. Endocrinology 104, 1007-1011. 